\title{
Mobility of individual roach Rutilus rutilus (L.) in three weir-fragmented Belgian rivers
}

\author{
Caroline Geeraerts · Michaël Ovidio · \\ Hilde Verbiest · David Buysse · Johan Coeck • \\ Claude Belpaire $\cdot$ Jean-Claude Philippart
}

(C) Springer Science+Business Media B.V. 2007

\begin{abstract}
Adult roach Rutilus rutilus (L.) $(N=24 ; 19.9-36.1 \mathrm{~cm}$ FL) from three highly fragmented Belgian rivers were tagged with surgically implanted radio transmitters. Their seasonal movements were observed from March to August 2004 (circum reproduction period) in river stretches delimited by two physical barriers. In the three rivers, roach displayed similar patterns of movements which were mainly influenced by the date of observation (movements increased in late April-May) and water temperature (travel distances were more important when water temperature ranged between $10^{\circ} \mathrm{C}$ and $14^{\circ} \mathrm{C}$ ). Roach sometimes cleared physical obstacles. The mean distances travelled in each river were relatively short (max. $2.5 \mathrm{~km}$ ) and mainly influenced by the length of the study reach, which was delimited by physical barriers.
\end{abstract}

Guest editors: P. R. Almeida, B. R. Quintella, M. J. Costa and A. Moore

Developments in Fish Telemetry

C. Geeraerts $(\bowtie) \cdot$ H. Verbiest · D. Buysse .

J. Coeck · C. Belpaire

Research Institute for Nature and Forest, Duboislaan

14, 1560 Groenendaal (Hoeilaart), Belgium

e-mail: caroline.geeraerts@inbo.be

M. Ovidio - J.-C. Philippart

Biology of Behaviour Unit, Laboratory of Fish

Demography and Hydro ecology, University of Liège,

10 Chemin de la Justice, 4500 Tihange, Belgium
Keywords Roach · Migration · Telemetry ·

Barrier · Fragmentation · Seasonal movements

\section{Introduction}

Roach Rutilus rutilus (L.) is a dominant cyprinid fish in many rivers throughout the Eurasian mainland. It is common in rivers, lakes, canals and reservoirs, in streaming as well as in standing waters. It is a benthopelagic, potamodromous species that can survive in poor quality and fragmented rivers. It is a non-rogue fish, which lives in schools and forages in various environments such as the neighbourhood of aquatic vegetation but also in open water. Regardless of its strong tolerance to water disturbance, roach populations have rarely been protected and minimally studied (Vandelannoote et al., 1998).

Information on the behaviour and mobility of individual roach is necessary to understand its ecology and adaptive behaviour to survive in highly disturbed environments. Earlier studies during the 1960s in lakes and rivers suggested that roach move over short distances (Williams, 1965; Stott, 1967) but more recent studies demonstrated that roach sometimes migrate over several kilometers (Baade \& Fredrich, 1998) and display homing behaviour to spawning areas (Goldspink, 1977; L'Abée-Lund \& Vøllestad, 1985). The 
objective of this study is to analyse the seasonal movements of individual roach in three highly fragmented rivers in Belgium and to observe how roach adapt their use of space in river stretches delimited by up- and downstream physical obstacles.

\section{Materials and methods}

Study area

The study was performed simultaneously in three rivers in northern and southern Belgium (Fig. 1). The River Kleine Nete is a small lowland river in the northern part of Belgium, which belongs to the bream zone (Huet, 1949) of the River Scheldt basin (Fig. 1(1)). It is a $50 \mathrm{~km}$ long river with a drainage area of $815 \mathrm{~km}^{2}$. The River Kleine Nete has been canalised and straightened to improve drainage of the valley. Actually five weirs and two siphons fragment the main course of the Kleine Nete. The study site was situated in the slow flowing middle reach of the river in between weirs A and B (Fig. 1(1)). Weir B is equipped with a fish pass. The distance between these weirs is $7 \mathrm{~km}$. One tributary, the River Aa, enters into the Kleine Nete just upstream of the weir A. About 30 fish species are found in the River Kleine Nete of which roach is the most abundant. Annual discharge in the study reach ranges between 2.1 and $26.3 \mathrm{~m}^{3} \mathrm{~s}^{-1}$ and water temperature ranges between $0^{\circ} \mathrm{C}$ and $23^{\circ} \mathrm{C}$ (data from 1997 to 1999).

The River Grote Nete is a $60 \mathrm{~km}$ long small lowland river in the northern part of Belgium with a drainage area of $730 \mathrm{~km}^{2}$. The river also belongs to the River Scheldt basin (Fig. 1(2)) and is characterised as a bream zone (Huet, 1949). The upper part of the River Grote Nete has a strong meandering course while the middle and lower reach of the river is canalised and straightened. Six physical obstacles and four siphons

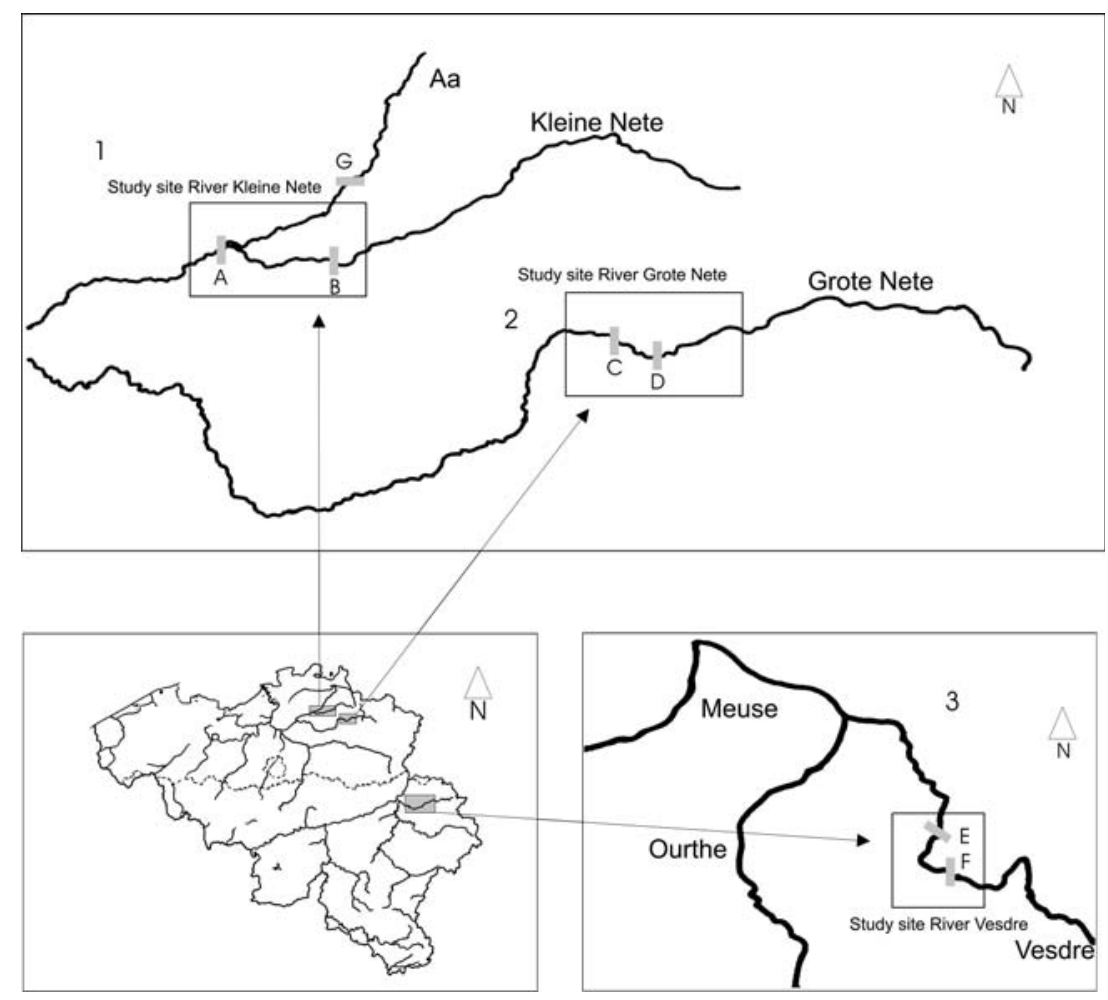

Fig. 1 Location of the three study areas in Belgium: (1) the River Kleine Nete, (2) the River Grote Nete and (3) the River Vesdre. Transverse bars represent the barriers that may interfere with the free circulation of fish. (A) weir
Grobbendonk, (B) weir Herentals equipped with a fish pass, (C) weir Meerhout, (D) water mill Meerhout, (E) weir Chaudfontaine, $(F)$ weir Hauster and $(G)$ weir on the River Aa, a tributary of the River Kleine Nete 
fragment the main course of the Grote Nete. The study site was situated in the slow flowing middle reach of the river in between weir $C$ and water mill D (Fig. 1(2)). The distance between these obstacles is $3 \mathrm{~km}$. The fish community consists of 25 species. Gudgeon Gobio gobio (L.) is the most abundant species, followed by roach. Annual discharge, ranges between 0.3 and $5.4 \mathrm{~m}^{3} \mathrm{~s}^{-1}$ and water temperature ranges between $0^{\circ} \mathrm{C}$ and $23^{\circ} \mathrm{C}$ (data from 1997 to 1999).

The River Vesdre is a $72 \mathrm{~km}$ long upland river in the southern part of Belgium and is part of the Meuse basin (sub-basin: $702 \mathrm{~km}^{2}$ ) (Fig. 1(3)). Twenty-nine physical obstacles fragment the main course of the River Vesdre. From 1850 to 1998 the Vesdre was highly polluted. Since 1998 water quality has improved due to the construction of water purification stations. The study site was situated in the lower reach of the river in between obstacles E and F (Fig. 1(3)). The distance between these obstacles is $1.2 \mathrm{~km}$. In the lower part of the Vesdre, the fish assemblage is a mix of the barbel/grayling zone (Huet, 1949) and consists of 20 species. Annual discharge ranges between 4 and $120 \mathrm{~m}^{3} \mathrm{~s}^{-1}$ (data from Water Division, D.G.R.N.E.) and water temperature ranges between $0^{\circ} \mathrm{C}$ and $23^{\circ} \mathrm{C}$.

\section{Capture, tagging and tracking}

In each river system $N=8$ roach $(>150 \mathrm{~mm}$ FL and $>150 \mathrm{~g}$ ) were sampled by DC electric fishing from 12 March to 8 April 2004 (Table 1). In the rivers Kleine and Grote Nete, roach were captured at different sites in the study reach. In the River Vesdre, roach were captured at the same place. Roach were anaesthetised in a solution of 2-phenoxy-ethanol $\left(0.2 \mathrm{mg} \mathrm{L}^{-1}\right)$, and $40-42 \mathrm{MHz}$ internal implant radio transmitters (ATS Inc.) were inserted into the body cavity of the fish through a midventral incision (Ovidio \& Philippart, 2002). In order to avoid any adverse effect of long-term post-operation care on their behaviour, the fish were released at their exact capture site as soon as they had recovered and showed spontaneous swimming activity (about 20-30 min after surgery).

Tracking started the day after tagging. Locations were recorded during daylight, by triangulation using an ATS R2000 or Fieldmaster receiver with a loop antenna (ATS Inc.) from labelled marks lining the banks of the river. Roach were located daily in the rivers Grote Nete and Kleine Nete and located 2-5 times a week in the River Vesdre. Fish were tracked during a maximum of 160 days in the Grote Nete and Kleine Nete and during 114 days in the Vesdre (from March to July or August) in order to include the pre-spawning, spawning and postspawning period of the species (Vøllestad \& L'Abée-Lund, 1987; Baade \& Fredrich, 1998). Water temperature was monitored hourly by data loggers (TidBit, Onset Computer Corp.) and water flow was recorded hourly (data from the Water Division) in each river. To take into account the differences in intervals between fish locations in the three rivers, the movements were standardised to 'weekly mean distance travelled'

Table 1 Characteristics of tracked roach and specifications of implanted miniature radio-transmitters

\begin{tabular}{llll}
\hline & River Kleine Nete & River Grote Nete & River Vesdre \\
\hline Fish number & $1-8$ & $9-16$ & $17-24$ \\
Mean length, (min-max) $(\mathrm{mm})$ & $239(199-361)$ & $234(205-315)$ & $232(215-252)$ \\
Mean weight (min-max) $(\mathrm{g})$ & $204(156-308)$ & $225(196-559)$ & $238(172-295)$ \\
Sex ratio & 4 females/4 males & 3 females/5 males & 4 females/4males \\
Capture dates & $22 / 03-08 / 04 / 2004$ & $12-17 / 03 / 2004$ & $23 / 03 / 2004$ \\
Tracking duration (days) & $34-140$ & $17-160$ & $11-114$ \\
Transmitter model & ATS-F1170 & ATS-F1470 & ATS-F1580 \\
Transmitter weight in air $(\mathrm{g})$ & 4 & 4 & 3.6 \\
(\% of fish body mass) $($ min-max) & $2.0(2.6-1.3)$ & $1.8(2.0-1.0)$ & $1.5(2.1-1.2)$ \\
Transmitter length (mm) & 31 & 31 & 25 \\
Antenna & Internal coiled & Internal coiled & External (15 mm) \\
Battery life (days) & 200 & 390 & 390 \\
\hline
\end{tabular}



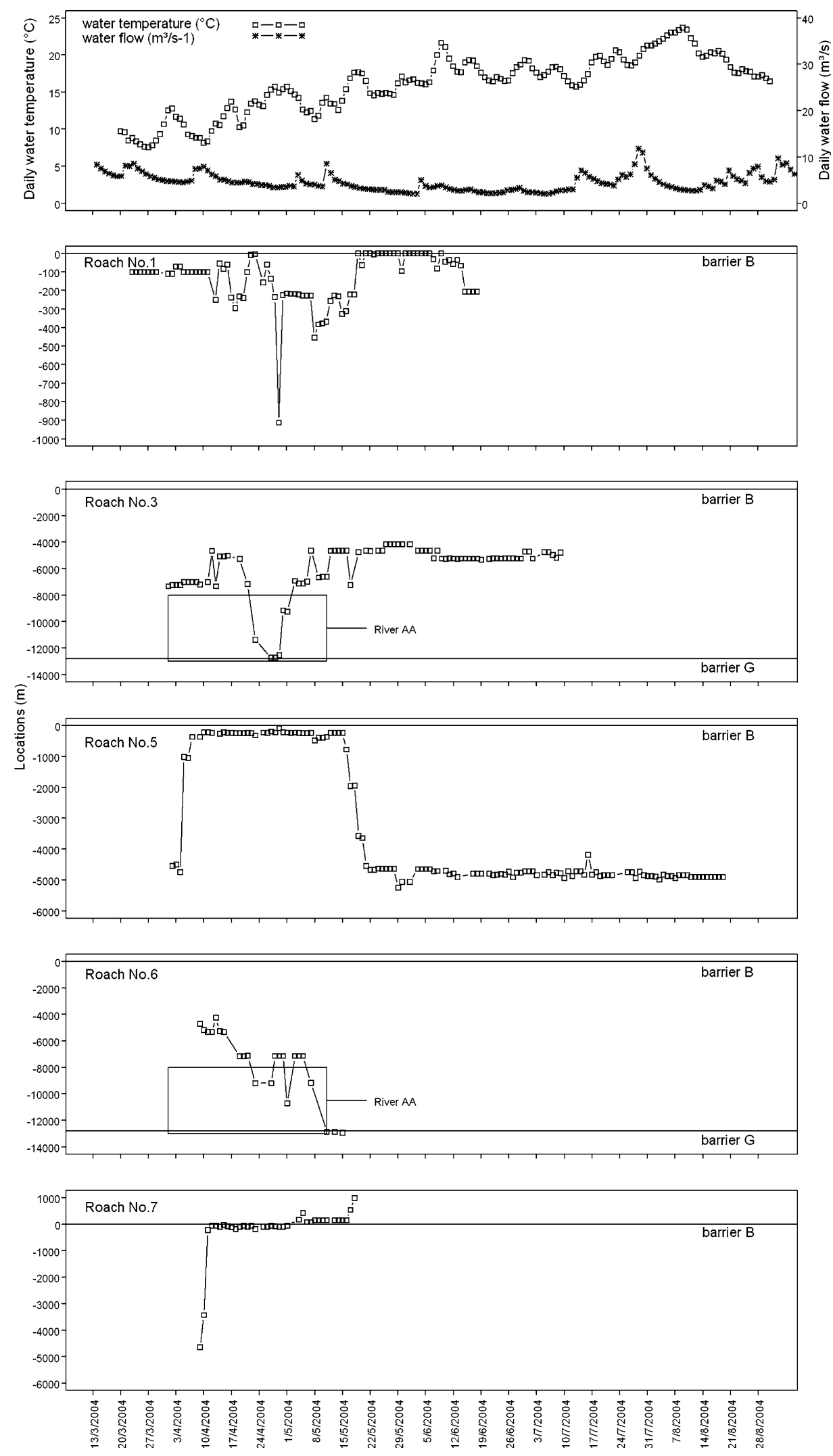
4 Fig. 2 Daily variations of water temperature $\left({ }^{\circ} \mathrm{C}\right)$ and water flow $\left(\mathrm{m}^{3} \mathrm{~s}^{-1}\right)$ in the River Kleine Nete from 13 March to 31 August 2004. Positions (m) of 5 radio-tagged roach in the River Kleine Nete. The point 0 corresponds to the most upstream barrier of the study reach. R2, R4 and R8 are not represented. R4 was lost and R2 and R8 show similar behaviour as R3

to perform statistical analysis. It corresponds to the mean distance travelled by roach during a one-week interval.

\section{Results}

The individual movements of representative tagged roach in the three rivers are illustrated in Fig. 2 (Kleine Nete), Fig. 3 (Grote Nete), and Fig. 4 (Vesdre).

At the beginning of April, when the water temperature approached $12^{\circ} \mathrm{C}$, roach in the River Kleine Nete demonstrated two distinct behavioural patterns (Fig. 2). (i) Three out of eight roach (R1, R5, R7) showed increased mobility and were frequently located in the upstream part of the study reach, in a faster flowing zone $200 \mathrm{~m}$ downstream of the weir and fish pass (obstacle B). They stayed there until the beginning of May, after which they homed to their capture site. Roach R7 made an upstream movement and cleared the fish pass (of obstacle B) after which it was lost. (ii) The other individuals (R2, R3, R6, R8) stayed close to their capture site until water temperature rose above $14^{\circ} \mathrm{C}$. They then made a downstream migration (about 3-6 km) into a tributary, the River Aa (Fig. 1(1)). Roach R3 and $\mathrm{R} 8$ made several up- and downstream movements before returning at the beginning of May to a location nearby their capture site in the River Kleine Nete. Roach R6 continued ascending the River Aa and cleared a temporarily flat lying weir (obstacle G) after which it was lost. After this period when the water temperature rose to $23^{\circ} \mathrm{C}$, roach showed lower mobility and the net length of the daily journeys generally decreased. Roach $\mathrm{R} 2$ and $\mathrm{R} 8$ are not represented in Fig. 2 but had similar movement patterns as described in (ii). Roach R4 was lost for unknown reasons and its movements are not described.
From late March to mid-April, when the water temperature increased from $7^{\circ} \mathrm{C}$ to $13^{\circ} \mathrm{C}$, the roach (R9, R10, R11, R13 and R14) in the River Grote Nete exhibited frequent up- and downstream movements (max. $860 \mathrm{~m}$ between two locations) alternated with periods of lower mobility (Fig. 3). From 14 April to 29 May, when the water temperature varied from $11^{\circ} \mathrm{C}$ to $18^{\circ} \mathrm{C}$, roach showed increased mobility and were frequently located in the upstream part of the study reach, in a faster flowing zone $500 \mathrm{~m}$ downstream the water mill (obstacle D). After this period, when the water temperature rose to $22^{\circ} \mathrm{C}$, roach frequently moved between two locations but the net length of the daily journeys generally decreased. Roach R10 and R13, contrary to the other roach, stayed in an upstream part of the river. Roach R12, R15, R16 are not represented in Fig. 3. Roach R12 was lost after a month. Roach R15 and R16 showed similar movement patterns as described for roach R9 and R10, respectively.

In the River Vesdre, roach R18, R20 and R23 were lost for unknown reasons. Until late April, in the River Vesdre, roach demonstrated low mobility and were mainly concentrated near their capture site (Fig. 4). However, some individuals displayed up- and downstream movements during increased flow conditions. When water temperature rose above $12^{\circ} \mathrm{C}$, in late April, roach demonstrated two main behavioural patterns. (i) Some individuals (R17 and R24) moved downstream. Roach R17 made a fast downstream movement of about 1,700 m on 22 April 2004 and passed the Chaudfontaine weir (obstacle E). Roach R24 moved upstream over $300 \mathrm{~m}$ on 26 April and immediately started a progressive downstream migration of about 2,000 $\mathrm{m}$ that finished on 10 May. Then it moved upstream over $1 \mathrm{~km}$ to a faster flowing part of the river situated downstream the obstacle E. (ii) The other individuals stayed in the $1.2 \mathrm{~km}$ long stretch between the

Fig. 3 Daily variations of water temperature $\left({ }^{\circ} \mathrm{C}\right)$ and water flow $\left(\mathrm{m}^{3} \mathrm{~s}^{-1}\right)$ in the River Grote Nete from 13 March to 31 August 2004. Positions (m) of 5 radio-tagged roach in the River Grote Nete. The point 0 corresponds to the most upstream barrier of the study reach. R12, R15 and R16 are not represented. R12 was lost and R15 and R16 show similar behaviour as R9 and R10 respectively 

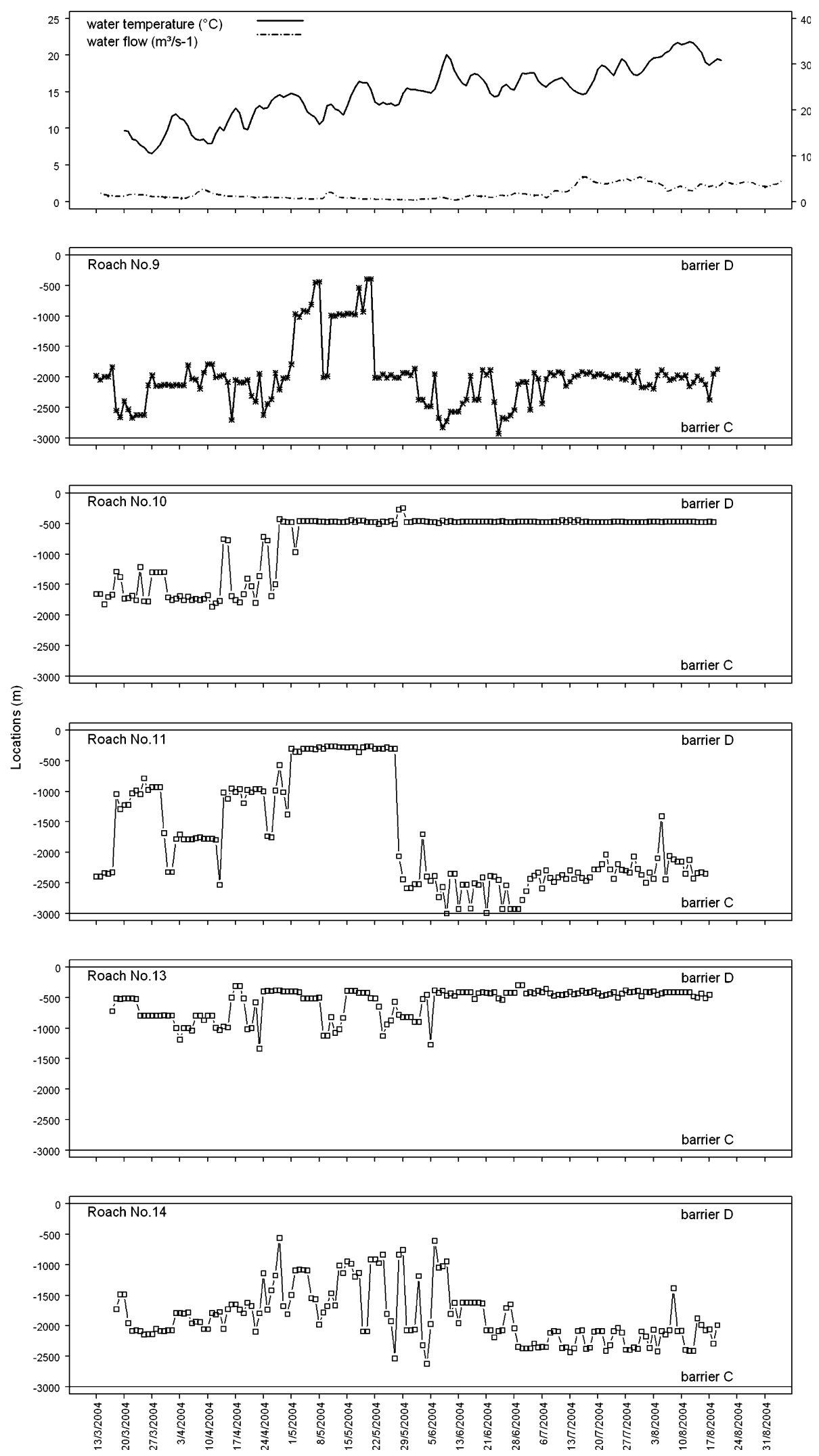

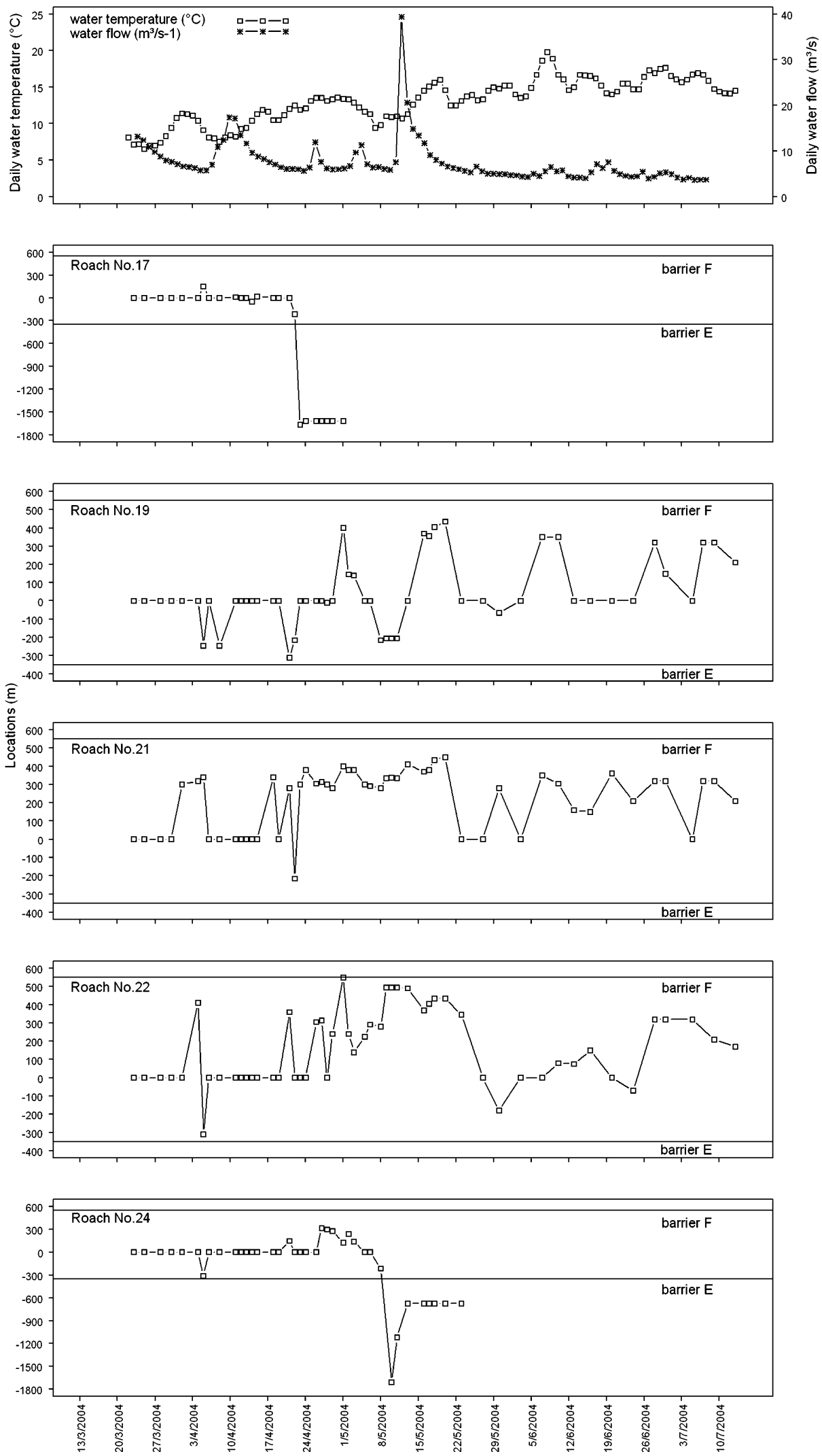
4 Fig. 4 Daily variations of water temperature $\left({ }^{\circ} \mathrm{C}\right)$ and water flow $\left(\mathrm{m}^{3} \mathrm{~s}^{-1}\right)$ in the River Vesdre from 13 March to 10 July 2004. (2) Positions (m) of 5 radio-tagged roach in the River Vesdre. The point 0 corresponds to the capture site of the roach. Roach R18, R20 and R23 were lost for unknown reasons and were not represented

obstacles $\mathrm{E}$ and $\mathrm{F}$. In mid-May, when the water temperature increased and reached $14^{\circ} \mathrm{C}$ for the first time, roach R19, R21 and R22 showed increased mobility and were frequently located in the upstream part of the study reach in a faster flowing zone of $300 \mathrm{~m}$ downstream the obstacle F. After this period, when the water temperature rose to $20^{\circ} \mathrm{C}$, roach continued to move between the downstream and upstream parts of the study area but the net length of the daily journeys generally decreased and they never cleared the obstacles in upstream direction.

When grouping the weekly mean distance travelled by roach in the three rivers (Fig. 5), it appeared that movements increased from the beginning of April until mid-May when water temperature fluctuated between $10^{\circ} \mathrm{C}$ and $14^{\circ} \mathrm{C}$. From mid-May, when water temperature rose above $14^{\circ} \mathrm{C}$ and the water flow decreased, the weekly mean distance travelled by the fish decreased and roach were less active. On 25 July and 15 August, two striking peaks (in weekly mean distance) corresponded to increased upstream distances travelled by three fish in the rivers Kleine Nete and Grote Nete (Fig. 5).

Roach movements were most important in the $10-14^{\circ} \mathrm{C}$ water temperature intervals that mainly occurred during April and May (potential spawning period) except for the two peaks in July and August. A significant difference in the weekly mean distance travelled was observed when grouping the roach movements (of the three water courses) into three categories of water temperature $\left(<10^{\circ} \mathrm{C} ; 10-14^{\circ} \mathrm{C} ;>14^{\circ} \mathrm{C}\right.$; KruskalWallis, $p<0.05)$. Similar analyses were performed to test the influence of water flow on roach movements, but no statistical relationship was found.

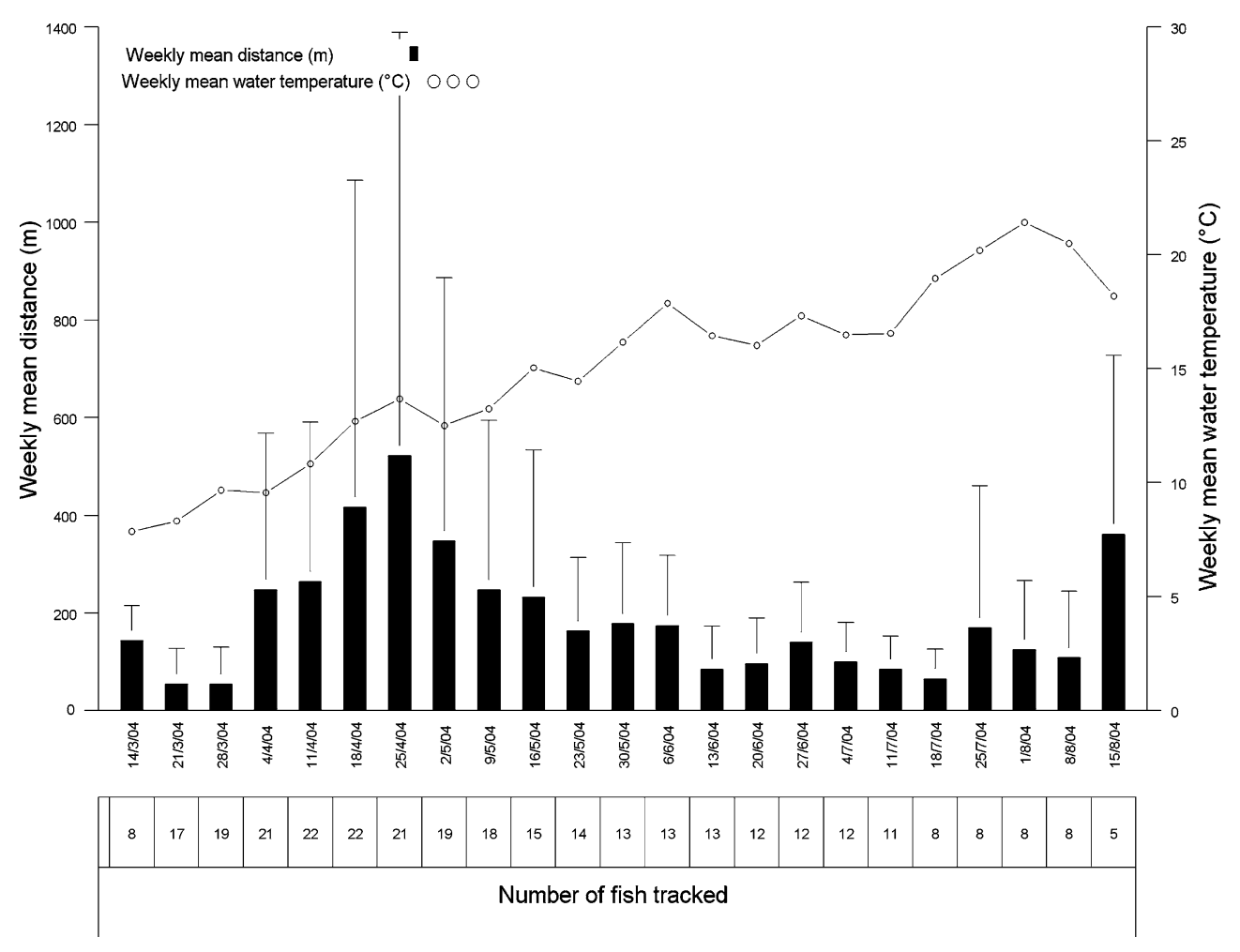

Fig. 5 Weekly mean distance $(\mathrm{m})$ travelled by roach, in the three rivers, in relation to the mean weekly water temperature $\left({ }^{\circ} \mathrm{C}\right)$ of the three rivers. Error bars represent standard deviation 
The weekly mean distances travelled by roach during the overall study period were different between rivers (Fig. 6). In the River Kleine Nete, where fish migration is unobstructed for the first $14 \mathrm{~km}$ of the reach (first barrier in the River Aa), the mean distance travelled was about $475 \mathrm{~m}$ (Fig. 6). In the rivers Grote Nete and Vesdre, the free migration reach is limited to respectively 3 and $1 \mathrm{~km}$, by which the weekly mean distance travelled diminished to 145 and $86 \mathrm{~m}$, respectively. Weekly mean distances travelled were significantly different between the rivers Kleine Nete and Grote Nete ( $p<0.0001$; Scheffe $f$-test) and between the rivers Kleine Nete and Vesdre $(p<0.0001$; Scheffe $f$-test $)$. No differences were observed between the rivers Grote Nete and Vesdre ( $p=0.48$; Scheffe $f$-test $)$.

\section{Discussion}

Transmitter weight, as a percentage of the fish's body mass, is the primary constraint to limit the effect of the tagging procedure on fish behaviour (Mulcahy, 2003). A commonly cited recommendation (Winter, 1983) is to limit the weight of internal transmitters to $\leq 2 \%$ of the fish's body mass. However, recent studies demonstrated that, at least for some species, this value might be largely increased, sometimes up to $12 \%$ (Jepsen et al., 2002). In this study, in order to minimise the potential effect of the tag on roach behaviour, the transmitters represented a maximum of $1.5 \%$ of the fish body mass.

The duration and dynamics of the roach movements were generally quite similar between individuals in the tracked upland and lowland rivers. Roach showed maximum activity from the beginning of April until the end of May and they were frequently located in the faster flowing parts of their study reaches during that time period. Even though spawning activity could not be observed, it can be assumed that these movements were related to spawning activity as this period corresponds to the reproduction time of the species in similar environments (Vøllestad \& L'Abée-Lund, 1987; Baade \& Fredrich, 1998, Lucas et al., 1998; Poncin, 1994). Fast flowing zones in rivers were already described as potential spawning areas for roach (Holcik \& Hruska, 1966; Diamond, 1985). Outside of this period (during the pre- and post-spawning period) roach frequently moved between different locations but the net length of the daily journeys were generally smaller. Distances travelled by roach increased significantly when water temperature varied between $10^{\circ} \mathrm{C}$ and $14^{\circ} \mathrm{C}$, which also corresponds to the late April-May period. Baade \& Fredrich

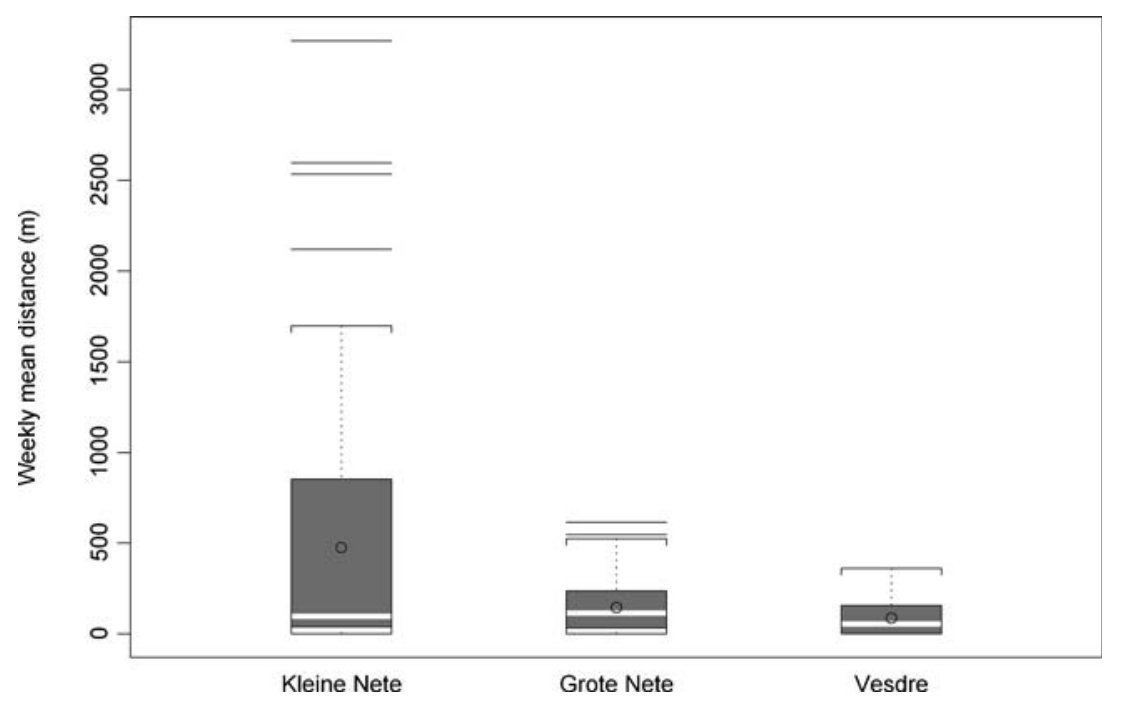

Fig. 6 Weekly mean distance travelled by tagged roach in the three rivers during the overall study period. Values are median, percentiles 5, 25, 75 and 95. Bars indicate outlier values and circles indicate weekly mean distances 
(1998) noticed that there is a highly significant distinction in mobility rates and activity levels between April and May (when fish are most active) and other times. The longer movements were observed during spawning season.

No statistical relationship was observed between water flow and distance travelled although some rare winter movements were observed during very high flow events. In lake Årungen (south-eastern Norway), Vøllestad \& L'AbéeLund (1987) suggested that spawning activity is regulated by water flow and water temperature and suggested that roach spawned synchronously in years with rapid increases in temperature, whereas they had a prolonged spawning period in years with low or with slow increases in water temperature. It has previously been demonstrated that photoperiod is the principal factor synchronizing the start of the spawning in roach (Worthington et al., 1982). In unstable environments, the use of predictable cues such as day length will be positively selected. Temperature however is important in regulating the intensity and duration of the spawning (Worthington et al., 1982).

Although the dynamic of the roach movements and the activity levels were similar in the three rivers, our results demonstrate that the extent of the movements observed was mainly related to the distance between physical barriers in the study areas. Distances travelled were more pronounced in the River Kleine Nete where the distance between the physical barriers is $14 \mathrm{~km}$ (first barrier on the River Aa tributary). Upstream from the downstream weir, free entrance in the River Aa tributary is possible, and the upstream weir (in the River Kleine Nete) is equipped with a fish pass (Fig. 1(1)). On the other hand, in the River Vesdre, where the distance between the physical barriers is only $1.2 \mathrm{~km}$, the distances travelled were much shorter and the proportion of roach moving downstream during the reproduction period was more pronounced.

Our results suggest that roach were not frequent obstacle leapers (at least in the upstream direction) and they were able to complete all of their biological activities in limited stretches of rivers in highly fragmented environments. As well, they sometimes demonstrated up- and downstream movements during the reproduction period in search of available spawning habitat. In a $32 \mathrm{~km}$ unfragmented stretch of the River Spree (Germany), Baade \& Fredrich (1998) observed that roach migrated up to $10 \mathrm{~km}$ upstream to spawn. Some studies however showed that roach could sometimes clear small physical obstacles. Lucas et al. (1998) demonstrated that radiotracked roach ascended the Skip Bridge weir on the Nidd (United Kingdom) and moved further upstream to spawning areas. Svärdson (1951) observed a roach that was trapped in a wirenetting, jumping at least $15 \mathrm{~cm}$ above the water level.

The roach tracked in three fragmented rivers showed similar patterns of movements that were mainly influenced by the date of observation and the water temperature. The distances travelled were relatively short $(\max .12 .7 \mathrm{~km})$ and mainly influenced by the length of the study reach, delimited by physical barriers. Nevertheless roach were able to adapt their behaviour to the habitat fragmentation by completing their life cycles in reaches sometimes shorter than $2 \mathrm{~km}$. This might partially explain their subsistence in highly disturbed environments, however further studies are needed for a better understanding of the longterm effects of the habitat fragmentation on roach populations.

Acknowledgements This study was part of the FISHGUARD project 'Impact assessment and remediation of anthropogenic interventions on fish populations' financed by the Belgian Federal Office for Scientific, Technical and Cultural Affairs. The authors wish to thank D. Hennebel, R. Baeyens, S. Martens, G. Rimbaud and Y. Neus for field support. We are grateful to P. Verschelde and M. Melsen for their assistance with the draft of the graphs, F. Coopman for drawing the maps and two anonymous referees for their critical comments. We also would like to thank J. Carr for reviewing and providing constructive comments.

\section{References}

Baade, U. \& F. Fredrich, 1998. Movement and pattern of activity of the roach in the River Spree, Germany. Journal of Fish Biology 52: 1165-1174.

Diamond, M., 1985. Some observations of spawning by roach, Rutilus rutilus L., and bream, Abramis brama L., and their implications for management. Aquaculture and Fisheries Management 16: 359-367. 
Goldspink, C. R., 1977. The return of marked roach (Rutilus rutilus L.) to spawning grounds in Tjeukemeer, The Netherlands. Journal of Fish Biology 11: 599-603.

Huet, M., 1949. Aperçu de la relation entre la pente et les populations piscicoles des eaux courantes. Schweizerische Zeitschrift für Hydrologie 11: 332-351.

Holcik, J. \& V. Hruska, 1966. On the spawning substrate of roach, Rutilus rutilus L., and bream, Abramis brama L. and notes on the ecological characteristics of some European fishes. Vestnik Ceskoslvenske Spolecnosti Zoologicke 30: 22-29.

Jepsen, N., A. Koed, E. B. Thorstad \& E. Baras, 2002. Surgical implantation of telemetry transmitters in fish: how much have we learned. Hydrobiologia 483: 239248.

L'Abée-Lund, J. H. \& L. A. Vøllestad, 1985. Homing precision of roach Rutilus rutilus in Lake Aarungen, Norway. Environmental Biology of Fishes 13: 235239.

Lucas, M. C., T. J. Thom, A. Duncan \& O. Slavik, 1998. Coarse Fish Migration Occurrence, Causes and Implications. Technical Report W152, Environment Agency, 161.

Mulcahy, D. M., 2003. Surgical implantation of transmitters into fish. ILAR Journal 44(4): 295-306.

Ovidio, M. \& J. C. Philippart, 2002. The impact of small physical obstacles on upstream movement of six species of fish (Synthesis of a-year telemetry study in the River Meuse basin). Hydrobiologia 483: 55-69.

Poncin, P., 1994. La reproduction des poissons de nos rivières. Cahiers d'Ethologie 13: 317-342.
Stott, B., 1967. The movements and population densities of roach (Rutilus rutilus L.) and gudgeon (Gobio gobio L.) in the River Mole. Journal of Animal Ecology 36: 407-423.

Svärdson, G., 1951. Spawning behaviour of Leuciscus leuciscus (L.). Reports of the Institute of Freshwater Research, Drottingholm 33: 199-203.

Vandelannoote, A., R. Yseboodt, B. Bruylants, R. Verheyen, J. Coeck, J. Maes, C. Belpaire, G. Van Thuyne, B. Denayer, J. Beyens, D. De Charleroy \& P. Vandenabeele, 1998. Atlas van de Vlaamse Beek- en Riviervissen. Water-Energik-Vlario (WEL), Wijnegem, 1-303.

Vøllestad, L. A. \& J. H. L'Abée-Lund, 1987. Reproductive biology of stream-spawning roach, Rutilus rutilus. Environmental Biology of Fishes 18: 219-227.

Williams, W. P., 1965. The population density of four species of freshwater fish, roach (Rutilus rutilus L.), bleak (Alburnus alburnus L.), dace (Leuciscus leuciscus L.) and perch (Perca fluviatilis L.) in the River Thames at Reading. Journal of Animal Ecology 36: 407-423.

Winter, J. D., 1983. Underwater Biotelemetry. In Nielsen, L. A. \& D. L. Johnson (eds), Fisheries Techniques. American Fisheries Society, Bethesda, Maryland, 371-396.

Worthington, A. D., N. A. A. Macfarlane \& K. W. Easton, 1982. Controlled reproduction in the roach (Rutilus rutilus L). In Richter, C. J. J. \& H. J. H. Goos (eds), Reproductive Physiology of Fish. Proceedings of an International Symposium, Wageningen, 220-223. 